\title{
Benign familial polycythaemia
}

\author{
C. G. GEARY, H. E. AMOS, AND J. E. MACIVER \\ From the Clinical Laboratories, Manchester Royal Infirmary
}

SYNOPSIS An English family suffering from thalassaemia minor is described. Three generations are affected, and all the affected members had a considerably raised red cell count in the presence of slight or moderate anaemia, obviously abnormal peripheral films, and only slightly reduced M.C.H.C. values; and each had a moderately raised haemoglobin $A_{2}$ level, though foetal haemoglobin levels were normal.

The presentation of a family with erythrocytosis recalls the condition described in the older literature as benign familial polycythaemia which was, in some cases at least, thalassaemia minor. It is suggested that the presence of a raised red cell count is a more reliable distinguishing feature than the presence of target cells, or the serum iron level, in thalassaemia minor.

Some authorities (Wintrobe, 1961; De Gruchy, 1964) recognize benign familial polycythaemia as a clinical entity and the present report describes an English family which appears to fulfil the diagnostic criteria. As discussed below, it is likely that many of the reported cases had thalassaemia minor; this proved to be the case in our family. Thalassaemia is now well known (Israëls and Turner, 1955; Havard, Lehmann, and Scott, 1958; Garrett and Morton, 1960; Bourne, Roath, Watson Williams, and Israëls, 1964; Zürcher, Loos, and Prins, 1966) to occur in people of northern European stock and usually presents as a refractory hypochromic anaemia, but presentation as an erythrocytosis is less well documented, at least in the British literature.

\section{METHODS}

Standard haematological methods were used (Dacie and Lewis, 1963); red cell counts were performed using a Coulter counter. Starch-gel electrophoresis at $p \mathrm{H} 8.4$, as described by Sunderman (1963), was used for the identification and quantitation of haemoglobin $A_{2}$. Foetal haemoglobin was estimated by Singer's alkaline denaturation method as modified by Went and MacIver (1961).

The red cell mass of the propositus was estimated by labelling $22 \mathrm{ml}$. of his blood with $50 \mathrm{mC}$ of sodium ${ }^{51}$ chromate; $20 \mathrm{ml}$. was re-injected, and the blood volume was estimated by the method described by Dacie and Lewis (1963) and from this the red cell mass was calculated.

\section{FAMILY STUDY}

The propositus (R.S.), an apparently healthy master builder of 51 whose forbears were of pure Lancashire

Received for publication 1 September 1966. stock, attended hospital for investigation of 'rheumatism', described as 'pains' in the neck, back and thighs, not affecting any one joint and not related to weather conditions. There was no clinical or radiological evidence of arthritis, but the serum uric acid was slightly raised (7.2 mg. per $100 \mathrm{ml}$.).

In the course of routine haematological investigations, it was found that his red cell count was $7 \cdot 4 \mathrm{~m}$. per c.mm. though the haemoglobin was normal $(13.7 \mathrm{~g}$. per $100 \mathrm{ml}$.) as was the P.C.V. (47\%). The film showed many hypochromic cells, and considerable anisocytosis and poikilocytosis, with some target cells and an occasional stippled cell. The reticulocyte count was $2.2 \%$.

Initially, though his spleen was impalpable, it was thought that he was suffering from polycythaemia rubra vera, perhaps with occult haemorrhage, producing a hypochromic peripheral blood picture. The hyperuricaemia lent some support to this hypothesis. Further studies showed that this was very unlikely: the leucocyte alkaline phosphatase score was normal; although the marrow showed erythroid hyperplasia, there was no increase in megakaryocytes, eosinophils, or basophils; finally his red cell mass was estimated and found to be normal $(30 \mathrm{ml}$. per $\mathrm{kg}$. body weight). The serum iron $\mathrm{N}$ level was $115 \mu \mathrm{g}$. per $100 \mathrm{ml}$.; stainable iron in the marrow was considerably increased. An osmotic fragility test showed that the red cells were significantly resistant to hypotonic saline.

The morphological appearance of the peripheral blood film suggested the diagnosis of thalassaemia minor which was confirmed by the presence of a raised haemoglobin $A_{2}$, though the foetal haemoglobin was normal.

As all the patient's family lived in the Manchester area, it was comparatively easy to screen them for thalassaemia $\mathbb{D}$ minor, and studies revealed five cases in three generations

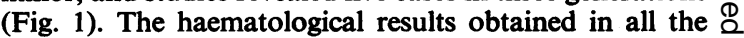
members of the family investigated are shown in $\sigma$ Table I. 
TABLE I

HAEMATOLOGICAL DATA IN A LANCASHIRE FAMILY WITH THALASSAEMIA

\begin{tabular}{|c|c|c|c|c|c|c|c|c|c|c|c|c|}
\hline & & & $\begin{array}{l}H b \\
(g . / 100 \mathrm{ml} .)\end{array}$ & M.C.H.C. & P.C.V. & $\begin{array}{l}\text { R.B.C.s } \\
(m .)\end{array}$ & M.C.H. & $\begin{array}{l}\text { Retic- } \\
\text { ulocytes }\end{array}$ & $\begin{array}{l}\text { Serum Iron } \\
(\mu \mathrm{g} / 100 \mathrm{ml} .)\end{array}$ & $\begin{array}{l}\text { Foetal } \\
\mathrm{Hb}\end{array}$ & $\begin{array}{l}H b \\
A_{2}\end{array}$ & $\begin{array}{l}\text { Film } \\
\text { Appearance }\end{array}$ \\
\hline \multirow[t]{9}{*}{$\begin{array}{l}\text { Ist } \\
\text { Generation } \\
\text { Father S. }\end{array}$} & & $\begin{array}{l}\text { Before iron } \\
\text { therapy }\end{array}$ & $11 \cdot 1$ & 29 & 38 & 6.98 & 16 & $3 \cdot 1$ & 40 & 0.3 & 4 & \multirow{2}{*}{$\begin{array}{l}\text { Basophil } \\
\text { stippling }++ \\
-\end{array}$} \\
\hline & & $\begin{array}{l}\text { After iron } \\
\text { therapy }\end{array}$ & $12 \cdot 8$ & 31 & 41 & $7 \cdot 75$ & 16 & $2 \cdot 8$ & 75 & - & - & \\
\hline & $\begin{array}{l}\text { 2nd } \\
\text { Generation } \\
\text { Raymond S }\end{array}$ & & $13 \cdot 7$ & 30 & 44 & 7.55 & 19 & $3 \cdot 8$ & 120 & 0.5 & $4 \cdot 6$ & \multirow{3}{*}{$\begin{array}{l}\text { Target cells }++ \\
\text { Basophil } \\
\text { stippling }++ \\
\text { Target cells }++ \\
\text { Basophil } \\
\text { stippling }++ \\
\text { Normal } \\
\text { Normal }\end{array}$} \\
\hline & Mrs. K. & & $10 \cdot 8$ & 27 & 37 & $6 \cdot 0$ & 15 & $2 \cdot 1$ & 65 & 0.6 & $4 \cdot 2$ & \\
\hline & $\begin{array}{l}\text { Mrs. H. } \\
\text { Mrs. M. }\end{array}$ & & $\begin{array}{l}12 \cdot 8 \\
11 \cdot 7\end{array}$ & $\begin{array}{l}32 \\
31\end{array}$ & $\begin{array}{l}30 \\
38\end{array}$ & $\begin{array}{l}4 \cdot 58 \\
4 \cdot 36\end{array}$ & $\begin{array}{l}28 \\
26\end{array}$ & $\begin{array}{l}2 \cdot 2 \\
7 \cdot 6\end{array}$ & $\begin{array}{l}95 \\
95\end{array}$ & $\begin{array}{l}0.1 \\
0.1\end{array}$ & $\begin{array}{l}1.4 \\
2.9\end{array}$ & \\
\hline & & $\begin{array}{l}\text { 3rd } \\
\text { Generation }\end{array}$ & & & & & & & & & & \\
\hline & & $\begin{array}{l}\text { Beryl K. } \\
\text { Jill K. }\end{array}$ & $\begin{array}{l}12 \cdot 8 \\
11 \cdot 1\end{array}$ & $\begin{array}{l}32 \\
28\end{array}$ & $\begin{array}{l}42 \\
39\end{array}$ & $\begin{array}{l}4 \cdot 64 \\
7 \cdot 17\end{array}$ & $\begin{array}{l}25 \\
16\end{array}$ & $\begin{array}{l}1 \cdot 2 \\
2 \cdot 4\end{array}$ & $\begin{array}{l}75 \\
75\end{array}$ & $\begin{array}{l}0.1 \\
0.7\end{array}$ & $\begin{array}{l}1.9 \\
6 \cdot 4\end{array}$ & \multirow{3}{*}{$\begin{array}{l}\text { Normal } \\
\text { Basophil } \\
\text { stippling + + } \\
\text { Normal } \\
\text { Basophil } \\
\text { stippling + + } \\
\text { Normal }\end{array}$} \\
\hline & & $\begin{array}{l}\text { Clive K. } \\
\text { Malcolm K. }\end{array}$ & $\begin{array}{l}12 \cdot 0 \\
.10 \cdot 5\end{array}$ & $\begin{array}{l}32 \\
29\end{array}$ & $\begin{array}{l}37 \\
36\end{array}$ & $\begin{array}{l}4 \cdot 54 \\
6 \cdot 65\end{array}$ & $\begin{array}{l}26 \\
16\end{array}$ & $\begin{array}{l}1 \cdot 4 \\
2 \cdot 4\end{array}$ & $\begin{array}{l}45 \\
75\end{array}$ & $\begin{array}{l}0.5 \\
0.4\end{array}$ & $\begin{array}{l}1.5 \\
6.0\end{array}$ & \\
\hline & & Dorothy S. & $13 \cdot 7$ & 33 & 41 & 4.88 & 28 & $2 \cdot 4$ & 105 & 0.19 & $1 \cdot 2$ & \\
\hline
\end{tabular}

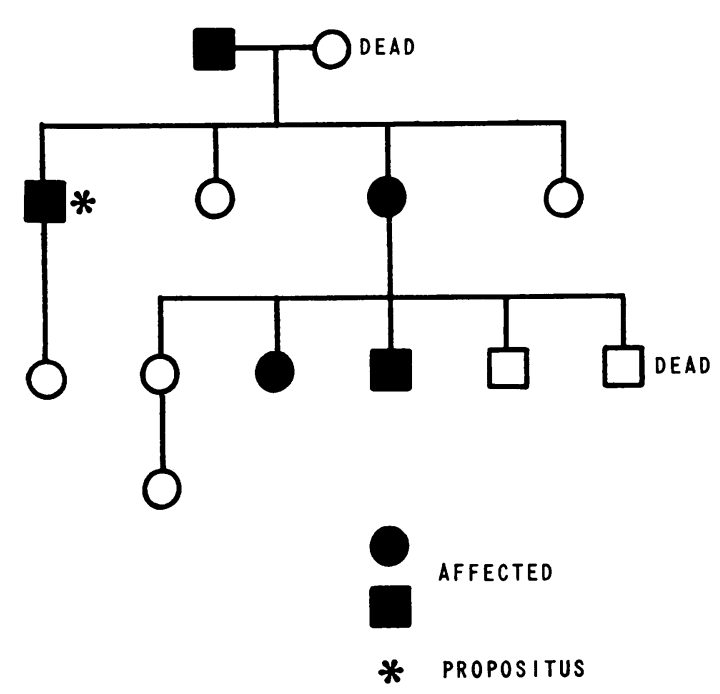

FIG. 1. Pedigree of the affected family

Father S, aged 74, who, like his son, had been a master builder, had enjoyed good health and had never been treated for anaemia. He was of normal stature and showed no skeletal deformities; there was no icterus or splenomegaly. Nevertheless, his blood count showed that he was significantly anaemic in spite of a raised red cell count. His blood film was typical of thalassaemia minor, with moderately frequent stippled cells; however, his serum iron level was low, and it seemed likely that he has an iron-deficiency anaemia as well. He also had hyperuricaemia (serum uric acid $=8.4 \mathrm{mg}$. per $100 \mathrm{ml}$.) but had never suffered from arthritis.
Mrs. K, aged 48, had been investigated for anaemia during pregnancy five years previously, and her marrow aspirate, obtained at the time, was available to us. It showed erythroid hyperplasia, like her brother's; stainable iron was reduced. She is slightly anaemic, though she, too, has a raised red cell count. Neither Mrs. H. nor Mrs. M was affected; their peripheral blood films showed no target or stippled cells and starch gel electrophoresis was normal. Mrs. $\mathbf{K}$. has four living children: daughter $\mathrm{BK}$, aged 23 ; daughter $\mathrm{JK}$, aged 18; son MK, aged 11; and son CK, aged 6. Another child had died of leukaemia in infancy. MK had been investigated for anaemia at the age of 5 years but no details were available. Both $\mathrm{JK}$ and $\mathrm{MK}$ had raised red cell counts and obviously abnormal peripheral films with a moderate number of target cells and some basophilic stippling; they also had elevated haemoglobin $\mathrm{A}_{2}$ levels; foetal haemoglobin levels were normal. BK had two children, one of whom was investigated: both she and her mother were normal, as was CK. All affected members of the family had low or very low mean corpuscular haemoglobin values.

\section{COMMENT}

The original presentation of the propositus, R.S., with a considerably raised red cell count suggested polycythaemia vera and the finding of other similar cases in the family recalled the concept of benign familial polycythaemia, first proposed by Spodaro and Forkner in 1933. Between 1914 and 1933 there were six case reports of familial polycythaemia, usually without raised white cell and platelet counts; (Bernstein, 1914; Tancre, 1917; Engelking, 1920; Doll and Rothschild, 1922; Kretschmer, 1926; 
Emile-Weil and Stieffel, 1926). Spodaro and Forkner described an Italian family in which many of the members had considerably raised red cell counts, though the haemoglobin values were usually only at the upper limit of normal, while the white cell and platelet counts were normal (Spodaro and Forkner, 1933). Splenomegaly was present in several but there was no hypertension. The authors believed that this was a benign form of polycythaemia, distinct from polycythaemia rubra vera, and not associated with the complications of the latter disease. Nadler and Cohn (1939), writing six years later, when they reviewed the literature on the subject, regarded this article as one of the most authoritative, though they point out that the red cell mass was not measured. However, this same family was re-investigated by Daland and Strauss in 1948 and shown to be suffering from thalassaemia minor. Though there are occasional reports of polycythaemia rubra vera occurring in siblings it is doubtful whether there is a true entity of 'benign polycythaemia' if cases due to vascular shunts, and possibly the polycythaemia of stress, are excluded. A more recent report is that of Auerback, Wolff, and Mettier (1958), who describe two families, one of Italian descent, the other Scandinavian, in which high haemoglobin and red cell counts occurred in more than one member. The haemoglobin was reported as ' $A$ ', but further details are not available in their paper. Familial polycythaemia has been reported associated with a rare abnormal haemoglobin (Chesapeake) by Charache, Weatherall, and Clegg (1966).

The present family also illustrates another feature of thalassaemia, namely, that its resultant haematological abnormality 'breeds true' throughout a given family. While most cases of thalassaemia are characterized by a raised $A_{2}$ and a slight increase in F haemoglobin levels, this is not invariable: either one or the other may be raised or rarely, neither (Fessas, 1964). In this last case, the diagnosis can only be made on the morphology of the film, a refractory hypochromic anaemia, raised serum iron level and evidence of familial presentation: a raised red cell count might be expected and, if present, would be useful confirmatory evidence.

With the exception of the propositus, all affected members of the family were slightly anaemic, with a slight fall in the M.C.H.C., and a serum iron level at, or somewhat below, the lower limit of normal. It seems likely that this was due, at least partly, to concomitant iron deficiency, since, in thalassaemia minor, the iron stores are usually increased, as indeed they were in the case of the propositus. Nevertheless, cases of thalassaemia are recorded in which the plasma iron level was decreased (Weinstein and Beutler, 1962) and this parameter alone (like decreased osmotic fragility and the presence of target cells) cannot be used to distinguish between irondeficiency anaemia and thalassaemia minor: this is not true of a raised red cell count, which does not occur in untreated iron-deficiency anaemia. Father S., who had a lower haemoglobin than the other affected members of the family, responded to oral iron; his red cell count was raised before treatment and became considerably higher after it, but there was virtually no change in the M.C.H. value.

The significance of the hyperuricaemia in the propositus and his father was not explained; it was not thought that they suffered from articular gout. It may have been incidental, since haemolytic anaemia is not regarded as a cause of secondary gout. No records are available, in the older literature, of the serum uric acid levels in benign polycythaemia, but the affected families did not suffer from gout. It is possible that the pain of which R.S. complained was due to erythroid hyperplasia; alternatively, it might have been a manifestation of 'non-articular' gout.

Our thanks are due to Professor D. A. K. Black for kindly allowing us to report this family study, and to Miss Helen Hough, F.I.M.L.T., for much technical assistance.

\section{REFERENCES}

Auerback, M. L., Wolff, J. A., and Mettier, S. R. (1958). Pediatrics, 21, 54.

Bernstein, J. (1914). Three cases of polycythaemia rubra. $W$. Lond. med. J., 19, 207.

Bourne, M. S., Roath, O. S., Watson-Williams, E. J., and Israëls, M. C. G. (1964). Proc. IXth Cong. europ. Soc. Haemat., 1963, 521.

Charache, S., Weatherall, D. J., and Clegg, J. B. (1966). J. clin. Invest. 45,813 .

Dacie, J. V., and Lewis, S. M. (1963). Practical Haematology, 3rd ed. Churchill, London.

Daland, G. A., and Strauss, M. B. (1948). Blood, 3, 438.

De Gruchy, G. C. (1964). Clinical Haematology in Medical Practice, 2nd ed., p. 453. Blackwell, Oxford.

Doll, H., and Rothschild, K. (1922). Klin. Wschr., 1, 2580.

Emile-Weil, P., and Stieffel, R. (1926). Bull. mém. Soc. méd. Hôp. Paris, 50, 1248.

Engelking, E. (1920. Dtsch. med. Wschr., 46, 1140

Fessas, P. (1964). In Abnormal Haemoglobins in Africa. A Symposium Organized by the C.I.O.M.S., edited by J.H. P. Jonxis, p. 71. Blackwell, Oxford.

Garrett, J. V., and Morton, F. (1960). Proc. VIIIth Congr. europ. Soc. Haemat., 1959, 1058.

Havard, C. W. H., Lehmann, H., and Scott, R. B. (1958). Brit. med. J., $1,304$.

Israëls, M. C. G., and Turner, R. L. (1955). Lancet, 2, 1363.

Kretschmer, M. (1926). Kinderheilk., 40, 225.

Nadler, S. B., and Cohn, I. (1939). Amer. J. med. Sci., 198, 41.

Spodaro, A., and Forkner, C. E. (1933). Arch. intern. Med., 52, 593.

Sunderman, F. W., Jr. (1963). Amer. J. clin. Path., 40, 227.

Tancre, E. (1917). Dtsch. Arch. klin. Med., 123, 435.

Weinstein, E., and Beutler, E. (1962). Mechanisms of Anaemia, p. 204 McGraw-Hill, New York.

Went, L. N., and MacIver, J. E. (1961). Blood, 17, 166.

Wintrobe, M. M. (1961). Clinical Hematology, 5th ed., p. 795. Kimpton, London.

Zürcher, C., Loos, J. A., and Prins, H. K. (1966). Proc. Xth Congr. Soc. Haemat. 1965). In the press. 